\title{
References:
}

1. Vidpovidalnist za koruptsiini diiannia, pravovi zasady vidshkoduvannia zbytkiv, zavdanykh vnaslidok yikh vchynennia: navch.-metod. materialy / Yu. V. Baskakova, V. M. Havryliuk, P. V. Kachanova, H. O. Usatyi ; uporiad. O. V. Zhur. Kyiv: NADU, 2013. P. 39-40.

2. Antykoruptsiine zakonodavstvo: mizhnarodni standarty ta yikh zaprovadzhennia $\mathrm{v}$ Ukraini : metod. posib. / uklad.: V. I. Hryhoriev, M. A. Mykytiuk, H. O. Honcharuk. Kyiv, 2013. P. 12.

3. Bocharnykov Y. V. Zarubezhnyi opyt protyvodeistvyia korruptsyi. Analytycheskyi vestnyk Analytycheskoho upravlenyia Apparata Soveta Federatsyi Federalnoho Sobranyia Rossyiskoi Federatsyi. 2007. № 6 (351). P. 45.

4. Reziume stranovykh dokladov (zapyska sekretaryata OON), podhotovlennoe v ramkakh Konferentsyy hosudarstv - uchastnykov Konventsyy Orhanyzatsyy Ob'yedynennykh Natsyi protyv korruptsyy, Hruppoi po obzoru khoda osushchestvlenyia Konventsyy Orhanyzatsyy Ob'yedynennykh Natsyi protyv korruptsyy 7 yiunia 2011 hoda (h. Vena) [Elektronnyi resurs]. Rezhym dostupa: http://sartraccc.ru/Pub_inter/unvscorr.files/ V1183527r.pdf

5. Nevmerzhytskyi Ye. Problemy retseptsii antykoruptsiinykh mekhanizmiv rozvynenykh krain v ukrainsku praktyku [Elektronnyi resurs]. Viche. 2011. № 19. Rezhym dostupu : http://www.viche.info/journal/2731/

DOI https://doi.org/10.30525/978-9934-26-074-2-45

\section{ВРАХУВАННЯ ОКРЕМИХ ПРИНЦИПІВ КРИМІНАЛІЗАЦІЇ У ЧЕРГОВИХ ЗМІНАХ ДО СТАТТІ 209 КРИМІНАЛЬНОГО КОДЕКСУ УКРАЇНИ}

\author{
Гладковський М. О. \\ аспірант кафедри кримінального права \\ Київького національного університету імені Тараса Шевченка \\ м. Київ, Україна
}

3 моменту прийняття Кримінального кодексу України (далі - КК) ст. 209 «Легалізація (відмивання) майна, одержаного злочинним шляхом» можна віднести до переліку тих статей, що зазнали значної кількості змін. Останні зміни у цій статті відбулися у зв'язку з прийняттям Закону України від 6 грудня 2019 року № 361-IX «Про запобігання та протидію легалізації (відмиванню) доходів, одержаних злочинним шляхом, фінансуванню тероризму та фінансуванню розповсюдження 
зброї масового знищення» (далі - Закон) яким ця стаття була викладена в новій редакції.

Аналіз пояснювальної записки до проєкту Закону України від 25 вересня 2019 року (реєстр. № 2179) (далі - законопроєкт), який згодом і став Законом, вказує на те, що законопроєкт розроблено на виконання, зокрема, пунктів 35 та 586 плану заходів з виконання Угоди про асоціацію між Україною, з однієї сторони, та СС, Свропейським співтовариством з атомної енергії і їхніми державами-членами, з іншої сторони; пункту 36е Меморандуму про співпрацю між Україною та МВФ та з метою імплементації норм четвертої Директиви (СС) 2015/849 «Про запобігання використанню фінансової системи для відмивання грошей та фінансування тероризму». Як зазначено у пояснювальній записці законопроєкт спрямований на удосконалення та уточнення окремих норм законодавства 3 питань запобігання і протидії легалізації (відмиванню) доходів, а також узгодження та покращання положень законодавчих актів, що змінюються, забезпечення реалізації положень нових міжнародних стандартів у сфері протидії відмиванню коштів та боротьби з фінансуванням тероризму. Для цього, зокрема, пропонується удосконалення законодавчих аспектів, які впливають на якість розслідування злочинів з легалізації (відмивання) доходів, одержаних злочинним шляхом

Отже, з пояснювальної записки до законопроєкту слідує, що зміни, внесені до ст. 209 КК, обумовленні необхідністю додержання такого загальноправового системного принципу криміналізації, як принцип міжнародно-правової необхідності й допустимості криміналізації ${ }^{1}$.

Втім більш прискіпливий аналіз міжнародних стандартів у сфері протидії відмиванню коштів та боротьби з фінансуванням тероризму дозволяє зробити висновок, що цей принцип не було повною мірою враховано в кримінальному законодавстві України не лише у зв'язку із розробленням цілої низки нових міжнародно-правових актів у цій сфері, про які йдеться у пояснювальній записці до законопроєкту, але й значно раніше.

Так, 17 листопада 2011 року Україною було ратифіковано Конвенцію Ради Європи від 16 травня 2005 р. про відмивання, пошук, арешт та конфіскацію доходів, одержаних злочинним шляхом, та про фінансування тероризму (далі - Варшавська конвенція). Відповідно до п.

${ }^{1}$ Аналіз питань криміналізації здійснюється на підставі наукового дослідження «Основания уголовно-правового запрета. Криминализация и декриминализация» [3]. Як зазначено в цій роботі одним із загально правових системних принципів криміналізації $\epsilon$ принцип міжнародно-правової необхідності й допустимості криміналізації [3, с. 228]. 
3 ст. 9 «Злочини 3 відмивання грошей» Конвенції кожна Сторона може вживати таких законодавчих та інших заходів, які можуть бути необхідними для визнання злочинними відповідно до іiі внутрішнього законодавства всіх або деяких з діянь, зазначених у п. 1 цієї статті, в одному 3 наведених нижче випадків чи в обох, коли правопорушник: a) підозрював, що майно $є$ доходом; b) повинен був припустити, що майно є доходом. Крім цього, відповідно до п. 5 цієї статті кожна Сторона забезпечує відсутність визнання попереднього або одночасного засудження за предикатний злочин як передумови для засудження за відмивання грошей. Кожна Сторона забезпечує можливість засудження за відмивання грошей відповідно до цієї статті, коли доведено, що майно, про яке йдеться в пп. «а» чи «b п. 1 цієї статті, походило 3 предикатного злочину, без необхідності точного встановлення якого саме (п. 6 ст. 9 Варшавської конвенції).

Отже, з моменту ратифікації Варшавської конвенції Україна, з одного боку, взяла на себе зобов'язання забезпечити відсутність визнання попереднього або одночасного засудження за предикатний злочин як передумови для засудження за відмивання грошей. 3 іншого боку Варшавська конвенція була ратифікована, зокрема, 3 таким застереженням згідно 3 яким «Україна відповідно до п. 2 ст. 53 Конвенції заявляє, що не буде застосовувати п. 6 ст. 9 Конвенції» (абз. 2 п. 2 Закону України «Про ратифікацію Конвенції Ради Свропи про відмивання, пошук, арешт та конфіскацію доходів, одержаних злочинним шляхом, та про фінансування тероризму»).

Такий неоднозначний підхід до ратифікації міжнародно-правових зобов'язань не міг не відобразитись на ст. 209 КК у попередній редакції. Як слушно зазначає А.В. Айдинян попередня редакція ст. 209 КК містила примітку, в п. 1 якої розташовувалося визначення предикатного діяння [1, с. 309], а диспозиція ч. 1 цієї статті була сформульована таким чином, що вказувала на те, що відповідальність за легалізацію могла настати лише за наявності вироку за предикатний злочин ${ }^{2}$.

${ }^{2}$ Щоправда в ч. 9 ст. 216 Кримінального процесуального кодексу України (далі - КПК) містилось положення про те, що досудове розслідування у провадженнях із легалізації (відмивання) доходів, одержаних злочинним шляхом, проводиться без попереднього або одночасного притягнення особи до кримінальної відповідальності за вчинення суспільно небезпечного протиправного діяння, що передувало легалізації (відмиванню) доходів, одержаних злочинним шляхом, у кримінальних провадженнях за ст. 209 КК у разі, коли, зокрема: 1) суспільно небезпечне протиправне діяння, що передувало легалізації (відмиванню) доходів, одержаних злочинним шляхом, вчинено за межами України, а легалізація (відмивання) доходів, одержаних злочинним шляхом, - на території України; 
А.В. Айдинян слушно звертає увагу на те, що чинна редакція ст. 209 КК не описує предикатне діяння, однак у диспозиції ч. 1 ст. 209 КК йдеться про «майно, щодо якого фактичні обставини свідчать про його одержання злочинним шляхом». На їі думку, навіть поверхневий аналіз внесених змін дозволяє зробити висновок, що нове формулювання розмите й позбавлене однозначного розуміння. Які це мають бути фактичні обставини? Яких фактичних обставин досить для того, щоб ставити питання про визнання майна таким, що одержане злочинним шляхом, а отже, для порушення кримінального провадження за його легалізацію (відмивання)? [1, с. 309].

Не вдаючись до полеміки щодо з'ясування змісту цього питання зазначимо, що відповідні зміни у ст. 209 КК відбулися у зв'язку з тим, що в нашій державі на законодавчому рівні була реалізована спроба (вдала чи ні покаже час та подальші наукові дослідження в цій сфері) можливості притягнення до кримінальної відповідальності за легалізацію (відмивання) майна, одержаного злочинним шляхом за відсутності вирку за предикатний злочин на підставі непрямих доказів, які вказують, що майно одержано злочинним шляхом.

У зв'язку 3 подальшою імплементацією положень п. 3 ч. 9 Варшавської конвенції, які були зазначені вище, також зазнали змін ознаки суб'єктивної сторони складу злочину, передбаченого ч. 1 ст. 209 КК. Якщо попередня редакція прямо не вказувала на психічне ставлення суб'єкта до вчинюваної ним дії по відмиванню майна, то чинна редакція конкретизує: «<..> якщо ці діяння вчинені особою, яка знала або повинна була знати, що таке майно прямо чи опосередковано, повністю чи частково одержано злочинним шляхом» [1, с. 310].

Внесені зміни також матимуть суттєвий вплинуть на такий принцип криміналізації, як принцип процесуальної здійсненності переслідування ${ }^{1}$.

Під час вебінару в рамках експертного проекту White Collar Crime «Розслідування легалізації доходів одержаних злочинним шляхом та

2) факт вчинення суспільно небезпечного протиправного діяння, що передувало легалізації (відмиванню) доходів, одержаних злочинним шляхом, встановлений судом у відповідних процесуальних рішеннях. Разом із цим аналіз доволі незначної практики притягнення винних осіб до кримінальної відповідальності за ст. 209 КК, розміщеної в Єдиному державному реєстрі судових рішень, поки що не дав можливості віднайти хоча б один вирок, коли особу було притягнуто до кримінальної відповідальності за цією статтею у попередній редакції за відсутності попереднього або одночасного притягнення до кримінальної відповідальності за предикатний злочин. Законом зазначені положення були виключені з ч. 9 ст. 216 КПК. 
можливість такого розслідування без доведення предикатного злочину» один з учасників цього вебінару Олександр Красноборов підсумовуючи свій виступ зазначив, що якщо йдеться про повноцінний змагальний процес, то притягнення до кримінальної відповідальності за ст. 209 КК неможливо без встановлення хоча б якогось предикатного злочину, у результаті вчинення кого було одержано хоча б частину майна, що легалізується. Водночас єдиним практичним механізмом безпредикатного розслідування легалізації для сторони обвинувачення залишається інститут угод (глава 35 розділу VI КПК) або випадки повного визнання вини відповідним підозрюваним, що не потребує від сторони обвинувачення чіткого доведення предикатного злочину. В підтвердження цього свідчить судова практика, яка наразі існує [2].

На нашу думку давати остаточну відповідь на питання щодо відповідності змін до ст. 209 КК принципу процесуальної здійсненності переслідування ще зарано, оскільки пройшло замало часу 3 моменту внесення зазначених змін протягом якого мала б сформуватись відповідна судова практика.

\section{Література:}

1. Айдинян А.В. Легалізація (відмивання) майна, одержаного злочинним шляхом (ст. 209 Кримінального кодексу України): Аналіз нової редакції (відповідно до Закону України № 361-IX від 06 грудня 2019 р.). Юридичний науковий електронний журнал. 2020. № 7. С. $308-311$.

2. Вебінар в рамках експертного проекту White Collar Crime «Розслідування легалізації доходів одержаних злочинним шляхом та можливість такого розслідування без доведення предикатного злочину». URL: https://www.facebook.com/lugovyi.slava/videos/10225681636415988 (дата звернення: 18.04.2021).

3. Основания уголовно-правового запрета. Криминализация и декриминализация» / Кудрявцев В. Н., Дагель П. С., Злобин Г. А. и др.; под ред. В. Н. Кудрявцева и А. М. Яковлева. Москва: Наука, 1982. 304 с. 